\title{
Review on Analysis of Helical Spring used in Rear Suspension of Various Motorbikes
}

\author{
Miss. Kishori Balasaheb Salunkhe ${ }^{1}$, Prof. A. A. Kumbhojkar ${ }^{2}$, Prof. A. P. Shrotri ${ }^{2^{*}}$ \\ ${ }^{I}$ PG Student, Department of Mechanical Engineering, PVPIT Budhgaon, Maharashtra, India \\ ${ }^{2}$ Associate professor, Department of Mechanical Engineering, PVPIT Budhgaon, Maharashtra, India
}

*Corresponding Author: Prof. A. P. Shrotri, Associate professor, Department of Mechanical Engineering, PVPIT Budhgaon, Maharashtra, India

\begin{abstract}
Automobile suspension plays an elevated role in passenger comfort and stability of the vehicle. Normally Suspension system is made up of the coil spring and shock absorber. Objective of this work is to study and take review of the work carried out by various researchers in the area of "analysis of helical springs used in rear suspension for motor bikes involving various geometrical parameters as well as materials. By comparing expected performance of helical springs, the comparative chart is prepared, which is useful to formulate a problem to be under taken as a topic of $P G$ dissertation.
\end{abstract}

Keywords: Suspension system, Mono shock suspension, Robust design, Analysis of helical spring

\section{INTRODUCTION}

A motorcycle's suspension serves a dual purpose viz,

1) Contributing to the vehicle's handling and braking.

2) Providing safety and comfort by keeping the vehicle's passengers comfortably isolated from road noise, bumps and vibrations.

The motorcycle has a pair of fork tubes for the front suspension, and a swing arm with one or two shock absorbers for the rear suspension. There are two types of suspension system used in two wheeler vehicle.

\subsection{Dual Shock Suspension System}

An H-shaped swing arm is attached at the front to the motorbike frame. On both side there are basic coil spring units which provide the suspension. The shocks are inside the coil spring units. This style of suspension falls out of favor due to weight considerations. It was also not a especially robust design. It all got a bit bendy and flexible under extreme riding conditions, and the only way to make it stronger was to add more material, which added more weight and cost.

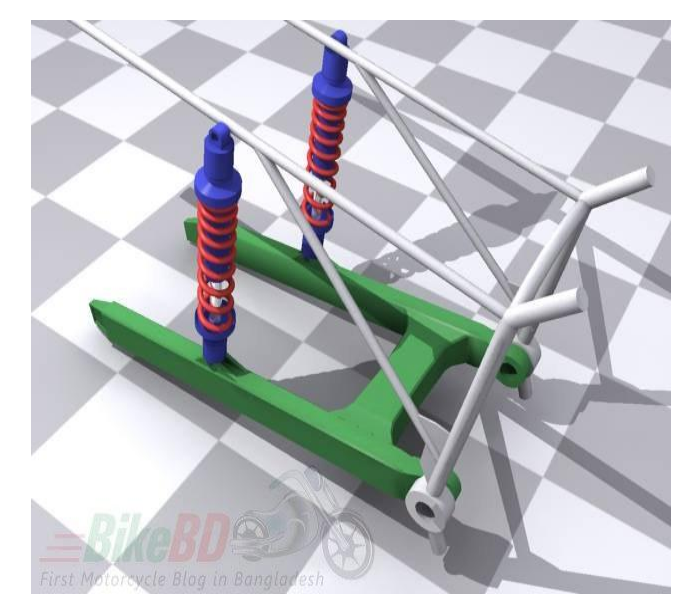

Fig1.1. Dual shock suspension [9] 


\subsection{Mono Shock Suspension System}

Mono shock is actually a Yamaha trademark, the Honda version is called Pro-Link. This was designed to reduce the weight by redesigning the rear suspension and removing one of the coil spring units. On the current mono shock designs, there is now a linkage at the bottom end which joins the coil over to the swingarm itself. It provides less weight and hence more speed. At cornering, the load on suspension system is uniform. So, the stability of mono shock suspension system is high.

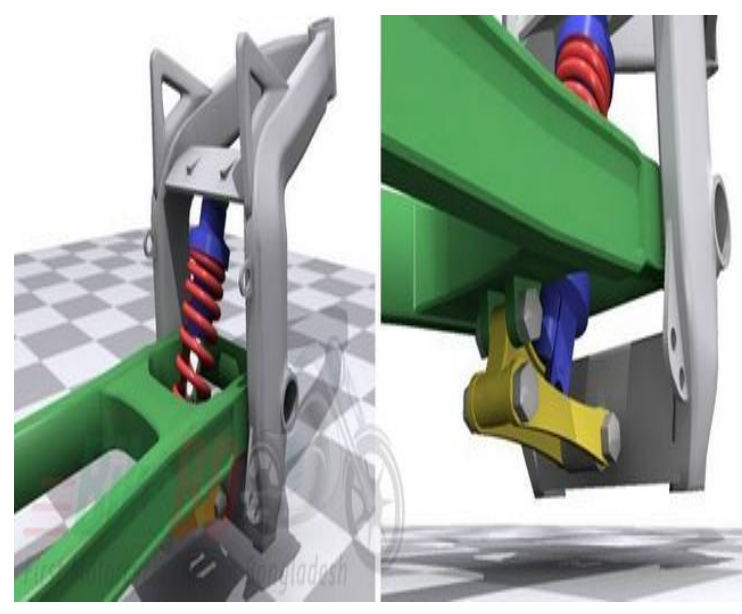

Fig1.2. Mono shock suspension [9]

\section{LITERATURE REVIEW}

Singh Pankaj etal ${ }^{[1]}$, the authors work is based on design and 3D modeling of helical compression spring used in mono shock suspension system of unicorn bike. The statistical structure analysis is done by FEA method in ANSYS for different spring materials and varying wire diameter of spring. The materials used for analysis are 1095, 5160, Carbon steel, Cobalt chrome, Chrome vanadium, Beryllium copper and the wire diameters are $12 \mathrm{~mm}, 14 \mathrm{~mm}$. Authors calculate the forces exerted on spring for different materials. For these calculations they assume that the vehicle is in motion. The authors compared the final results and choose the better among all results.

Dhiraj V. Shevale etal ${ }^{[2]}$, the main purpose of author work is to focus on the fatigue stress analysis and fatigue life of spring used in automobile suspension system. FEA method is used for analysis of spring. In finite element analysis, modeling is done by using CATIA V5 and analysis is in ANSYS 16.0. For calculations of forces on spring, authors consider the specifications of MARUTI SUZUKI Alto K10 .The fatigue life of spring is calculated by both analytical and FEA approach. Experimentation is carried out for validation of results. This experimental stress calculation is carried out by strain gauge with the help of Wheatstone network. Comparison of analytical result of fatigue life and stress is with FEA results.

N.Lavanya etal ${ }^{[3]}$, the author analyzes the safe load of the light vehicle suspension spring with different materials. The work is carried out on modeling the helical spring in Pro/E and analysis in ANSYS of primary suspension spring with two materials. The existing material is chrome vanadium and $60 \mathrm{Si} 2 \mathrm{MnA}$ steel is a new material. The conventional steel helical spring 60Si2 MnA is approved as best material for helical spring by reduction of deflection and overall stress.

Logavigneshwaran S. etal ${ }^{[4]}$, Author study the various parameters influencing the stress and deformation induced. After studying the various parameters, modeling is done by using Pro/ENGINEER. For analysis ANSYS software is used. The analysis is performed by considering the bike mass and with persons seated on the bike. Study is done by changing the wire diameter of the coil spring to check the best dimension for the spring in shock absorber.

Yogesh Chaubey etal ${ }^{[5]}$, The main purpose of author work is to analysis the failure in automobile coil spring. According to authors work, failure of spring is occurred due to fatigue Analysis, surface imperfection in coil spring, internal defects in coil spring, corrosion in coil spring etc. For finding the failure SEM images are used.SEM images of specimen have been captured and analyzed. It appears that suspension system has imperfection in the materials which are responsible for the premature failure. 
Prince Jerome Christopher.J etal ${ }^{[6]}$, The objective of research is to design and analyze the performance of Shock absorber of the coil spring. The shock absorber design is improved by reducing the diameter. Author designed a Shock Absorber used in $160 \mathrm{cc}$ bike .This shock absorber is modeled by using 3D parametric software called Pro/Engineer. The analysis is done by considering bike mass, loads, and number of persons seated on bike by using ANSYS.

Mallick Kamran etal ${ }^{[7]}$, The authors work is based on modeling, testing and analysis of helical suspension system used in two wheeler bike. . A typical two wheeler suspension spring for Hero Splendor $125 \mathrm{cc}$ is selected for the application. The various designs of springs are modeled by reducing the diameter of the existing spring in CATIA software. The analysis is carried out by considering bike mass, loads, and no of persons seated on bike by using ANSYS. The stress and deflections of the helical spring are determined by using finite element analysis approach. The author compares the actual spring with new spring for constant material. The results from finite element analysis are compared to the experimental values.

Aakash Bhatt etal ${ }^{[8]}$, Their work demonstrates the feasibility of adopting composite material for design of helical coil suspension system. An effort is made to carry out the design \& analysis of combination of steel and composite material, which has resulted into greater stiffness, with reduced weight of the spring.

\section{CONCLUdED SUMMARY}

Table1. Concluded summary

\begin{tabular}{|c|c|}
\hline $\begin{array}{c}\text { Paper reference } \\
\text { number }\end{array}$ & Conclusion \\
\hline$[1]$ & $\begin{array}{l}\text { From the results obtained in the analysis it can be concluded that for } 14 \mathrm{~mm} \text { wire diameter } \\
\text { coil spring cobalt chrome and chrome vanadium are better material than } 12 \mathrm{~mm} \text { wire } \\
\text { diameter carbon steel which is currently used. Chrome vanadium and cobalt chrome both } \\
\text { have high resistivity against corrosion, but cobalt chrome shows less deformation and } \\
\text { also the induced stress is comparatively less than chrome vanadium. Thus cobalt chrome } \\
\text { is the better one among the } 6 \text { material that were analyzed. }\end{array}$ \\
\hline$[2]$ & $\begin{array}{l}\text { Percentage error between FEA and analytical result of fatigue is } 2.64 \% \text { and } 2.61 \% \text { for } \\
\text { maximum shear stress. Experimental validation gives stresses up to } 105 \text { cycles. All the } \\
\text { stresses obtained experimentally are under the S-N curve which indicates that there is no } \\
\text { fatigue failure. Actual fatigue life of spring is estimated and catastrophic failures can be } \\
\text { avoided while improving the safety aspect of the vehicle. }\end{array}$ \\
\hline [3] & $\begin{array}{l}\text { The induced stress and strains values for low carbon structural steel are less as compared } \\
\text { to chrome vanadium. Also it improves the cyclic fatigue of helical spring. According to } \\
\text { the analysis it can be concluded that the low carbon structural steel material is best } \\
\text { suitable for production of helical springs compared to chrome vanadium steel. }\end{array}$ \\
\hline [4] & $\begin{array}{l}\text { Author redesigned the shock absorber. Due to this it is seen that the stress acting on the } \\
\text { shock absorber is reduced. The proposed improved design will reduce the deformation } \\
\text { and induced stress magnitude for the same applied loading conditions when compared } \\
\text { with the existing design. This increases the life of the shock absorber by reducing its } \\
\text { failures. The analytical results conform to the simulation results from the ANSYS. }\end{array}$ \\
\hline [5] & $\begin{array}{l}\text { For finding the reason behind the failure of suspension system, author uses metallurgical } \\
\text { analysis. Permanent failure of suspension system is done due to internal cracks and holes. } \\
\text { The material property is changed due to over tempered of coil spring causes loss of } \\
\text { ductility. }\end{array}$ \\
\hline [6] & $\begin{array}{l}\text { Author designed a Shock Absorber used in } 160 \mathrm{cc} \text { bike and modeled this shock absorber } \\
\text { by using 3D parametric software called Pro/Engineer. The design is modified by reducing } \\
\text { the diameter. After modeling and analysis it can be seen that the stress value is lesser in } \\
\text { our designed spring than in original. By comparing the results, the modified spring has } \\
\text { reduced in weight and it is safe. }\end{array}$ \\
\hline [7] & $\begin{array}{l}\text { The deflection in modified design of the helical spring is slightly higher than that of } \\
\text { baseline design- } 2 \text {. Maximum von-Misses stress is increased in a very minimal amount } \\
\text { but, it is less than yield strength of material. The mass of the design- } 2 \text { is } 25 \% \text { lighter than } \\
\text { baseline design- } 1 \text {. Design }-2 \text { with wire diameter }-6 \mathrm{~mm} \text { is efficient for the applied } \\
\text { loading conditions and stands out to be efficient design for spring especially at higher } \\
\text { loads. Thus, stainless steel with design- } 2 \text { is most suitable optimized design of helical } \\
\text { spring for manufacturing. }\end{array}$ \\
\hline
\end{tabular}




\begin{tabular}{|c|c|}
\hline [8] & $\begin{array}{l}\text { The yield strength in compression of e-glass is } 756 \mathrm{mpa} \text { while yield strength in tension is } \\
2415 \mathrm{mpa} \text {. The maximum value of deflection obtained is } 24.536 \mathrm{~mm} \text { which is less than } \\
25 \mathrm{~mm} \text {. Hence after carrying out the analysis of the spring using ANSYS, it is found that } \\
\text { the values of deflection and stress are within the permissible limits. The maximum value } \\
\text { of equivalent stress obtained is } 143.79 \text { mpa which is well within the permissible limit i.e. } \\
756 \mathrm{mpa} \text { (yield strength in compression for e-glass). } \\
\text { From above conclusion, it is prove that the helical springs made of E-glass can be used } \\
\text { for the applications of suspension system under } 1000 \mathrm{~N} \text { axial force. }\end{array}$ \\
\hline
\end{tabular}

\section{CONCLUSION}

The main purpose of authors work in above all research papers was to design a helical spring for various materials and for various coil geometry. For designing the helical spring, authors used finite element analysis and the software's like ANSYS, CATIA. The results obtained by these software's were compared with theoretical and experimental results. On this background, we propose to formulate a problem involving design and analysis of the helical spring for mono shock rear suspension in unicorn bike by using FEA software. The reference problem is taken up as a topic of my dissertation being currently pursuit.

\section{REFERENCES}

[1] Singh pankaj1, Amilkanthwar Rushikesh2, Walli Sanket3, Jasoliya Viraj4, Patel Kaushal5,Design and analysis of helical compression spring used in suspension system by finite element analysis method, International Research Journal of Engineering and Technology (IRJET), Volume: 04 Issue: 04, Apr -2017.

[2] Dhiraj V. Shevale1 \& Niranjan D. Khaire2,Analysis of helical compression spring for estimation of fatigue life, Imperial Journal of Interdisciplinary Research (IJIR) Vol-2, Issue-10, 2016 ISSN: 2454-1362,sep2016

[3] N.lavanya1, P.Sampath Rao2, M.Pramod Reddy3, Design and analysis of a suspension coil spring for automotive vehicle, N.Lavanya et al. Int. Journal of Engineering Research and Applications ,ISSN : 22489622, Vol. 4, Issue 9( Version 5), September 2014, pp.151-157.

[4] Logavigneshwaran S.1, Sriram G.2, Arunprakash R.3, Design and analysis of helical coil spring in suspension system, international journal for trends in engineering \& technology volume 9 issue 1 September 2015 - ISSN: 2349 - 9303.

[5] Yogesh Chaubey1, Chandan Kumar2, Sandeep Chauhan3, Failure analysis of suspension coil spring for passenger car through SEM microstructure investigation, International general of innovation in engineering and technology (IGIET), June 2016.

[6] Prince Jerome Christopher.j1, Pavendhan. R2,Design and analysis of two wheeler shock absorber coil spring, Discovery, Volume 23, Number 78, 4September 2014.

[7] Mallick Kamran1, Maner Abdullah2, Mdzeyad Hassan3, Gawade Shankar4, Raju Singh5, Design and analysis of two wheeler suspension system by fea approach, International Journal of Advance Engineering and Research Development Volume 5, Issue 02, February -2018.

[8] Aakash Bhatt, Anil Devani, Parth Zalavadiya ,Design analysis of helical spring of suspension system, IJEDR, Volume 4, Issue 3,ISSN:2321-9939,July.

[9] https://www.bikebd.com/a-brief-study-on-motorcycle-suspension-system/

\section{AUTHORS' BIOGRAPHY}

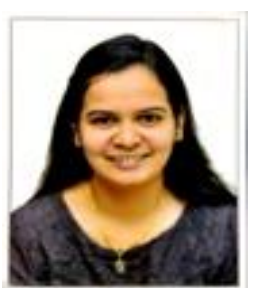

Miss. Kishori Balasaheb Salunkhe, B.E Mechanical, research interest in Preliminary design of front suspension setup for ATV of P.V.P.I.T baja team and optimization of suspension and steering parameters using lotus. Pursuing Masters in Design Engineering from P.V.P.I.T Budhgaon, Sangli, keen interest in "design and analysis of the helical spring for mono shock rear suspension in unicorn bike by using FEA software".

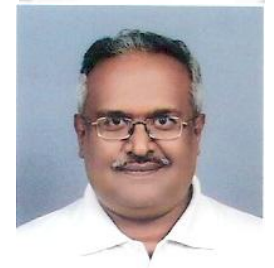

Prof. A. A. Kumbhojkar, has received M. Tech. in Mechanical- Design Engineering from IIT, Madras in1984. He is Associate Professor in Mechanical Engineering Department as well as Dean Academics, Padmabhooshan Vasantraodada Patil Institute of Technology, Budhgaon, Sangli, Maharashtra, India. His teaching experience is 35years and has guided more than 15 PG and 50UG projects. His research interest areas include Control Engineering, Mechatronics, Operations Research, Vibrations and Design Engineering. 


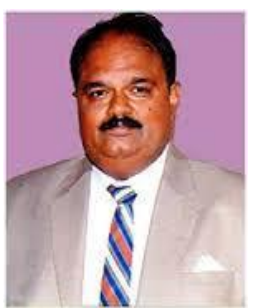

Prof. A.P.Shrotri is working as an Associate professor in P.V.P.I.T.BUDHAON, Dist. Sangli, Maharashtra, INDIA since 1986.He is a graduate in Mechanical Engineering, and a post graduate in mechanical Engineering, with specialization in Production Engineering. He has a remarkable teaching experience of 33 years. He has published twenty-nine papers at national/international level workshops/ conferences and forty four papers in international journals. He is the editorial/ advisory board member of thirty six international journals and worked as and on the board of reviewers of nineteen international journals. He has also worked as the editorial board/organizing committee member for twenty eight international conferences.

Citation: Miss. Kishori Balasaheb Salunkhe, et.al, (2019)" Review on Analysis of Helical Spring used in Rear Suspension of Various Motorbikes", International Journal of Modern Studies in Mechanical Engineering, 5(2), pp. 1-5. DOI: http://dx.doi. org/10.20431/2454-9711.0502001

Copyright: (C) 2019 Authors, This is an open-access article distributed under the terms of the Creative Commons Attribution License, which permits unrestricted use, distribution, and reproduction in any medium, provided the original author and source are credited. 